\title{
Efektivitas Model Pembelajaran Artikulasi dan Model Pembelajaran Talking Stick Terhadap Prestasi Belajar Matematika Ditinjau Dari Motivasi Belajar
}

\author{
Kiki Riska Ayu Kurniawati ${ }^{1}$, Habib Ratu Perwira Negara ${ }^{2}$ \\ ${ }^{1}$ Pendidikan Matematika, Universitas Islam Negeri Mataram, kikirak.2706@gmail.com \\ ${ }^{2}$ Pendidikan Matematika, STMIK Bumigora Mataram, habib.ratu27@gmail.com
}

\section{INFO ARTIKEL}

Riwayat Artikel:

Diterima: 09-08-2017

Disetujui: 24-09-2017

\section{Kata Kunci:}

Artikulasi

Talking Stick

Motivasi belajar

\section{A. LATAR BELAKANG}

Pembelajaran merupakan suatu kegiatan yang dilakukan guru guna mempengaruhi siswa dalam menuntut pengetahuan dengan jalan mengembangkan aktivitas dan kreativitas dalam kegiatan belajar mengajar. Peran guru bukan hanya sebagai narasumber saja bagi siswa dalam pembelajaran, tetapi mampu memotivasi belajar siswa, mampu mengorganisasi kegiatan belajar siswa,

\begin{abstract}
Abstrak: Penelitian ini bertujuan untuk mengetahui efektivitas masing-masing kategori model pembelajaran, motivasi belajar siswa dan interaksinya terhadap prestasi belajar matematika siswa. Populasi dalam penelitian ini adalah seluruh kelas VIII SMP Negeri 5 Madiun yang terdiri dari 4 kelas. Penentuan sampel menggunakan cluster random sampling. Metode pengumpulan data yang digunakan adalah metode tes dan metode angket. Uji hipotesis penelitian ini menggunakan anava dua jalan sel tak sama dengan taraf signifikansi 0,05. Kesimpulan dari hasil penelitian ini adalah (1) prestasi belajar matematika siswa yang menggunakan model pembelajaran Artikulasi lebih baik dari model pembelajaran Talking Stick, (2) jika ditinjau dari masing-masing tingkatan motivasi belajar, siswa yang memiliki motivasi belajar tinggi prestasi belajarnya jauh lebih baik dibandingkan dengan siswa yang memiliki motivasi belajar sedang maupun rendah dan (3) model pembelajaran Artikulasi lebih efektif dari model pembelajaran Talking Stick untuk meningkatkan prestasi belajar siswa, untuk setiap tingkat motivasi belajar siswa.
\end{abstract}

Abstract: The aims of this research were to find out the effectivennes of each categories of learning model, motivation to study and their interaction towards student mathematics learning achievement. The population was all students of grade VIII Five Junior High School of Madiun City consisted of four class. Sampling was done by cluster random sampling technique. The hypothesis test used unbalanced two ways analysis of variance at the significance level of 0.05. The conclution of this research that (1) the model of Articulation learning gives a better mathematics achievement than model of Talking Stick learning, (2) students with the high motivation to study had better achievement than students with the medium and low motivation to study, and (3) the model of Articulation learning was more effective than the model of Talking Stick learning to enhance students mathematics learning achievement for each level of students motivation to study. mampu menciptakan suasana belajar yang kondusif bagi siswa, mampu memberikan kesempatan untuk berkomunikasi secara bebas dan terarah pada siswa dalam proses pembelajaran, mampu sebagai fasilitator yang mempermudah siswa dalam proses belajar serta berperan sebagai evaluator hasil belajar siswa. Hal ini ditujukan supaya siswa dapat mengalami, memperoleh dan menemukan pengalaman baru dalam proses pembelajaran. Keberhasilan siswa dalam belajar tergantung cara 
penyajian materi pelajaran dan model pembelajaran yang diterapkan oleh guru.

Ada beberapa faktor yang mempengaruhi prestasi belajar siswa, yang salah satu diantaranya adalah motivasi. Motivasi merupakan faktor yang sangat penting dalam proses belajar guna mencapai prestasi yang diharapkan. Ini dikarenakan motivasi merupakan pendorong dan penggerak individu yang dapat menimbulkan dan memberikan arah bagi individu untuk melakukan aktivitas-aktivitas tertentu untuk mencapai tujuannya. Standar nilai, baik nilai ketuntasan belajar maupun kelulusan yang ditetapkan secara nasional yang harus dicapai oleh siswa dapat meningkatkan motivasi siswa dalam belajar dan berprestasi serta membuat siswa tertuntut untuk mengubah kebiasaan belajarnya ke arah yang lebih baik.

Matematika merupakan mata pelajaran yang mengarahkan siswa untuk berpikir logis, rasional, cermat, kritis, efektif dan efisien dalam memecahkan suatu masalah. Matematika merupakan dasar komponen penting bagi bidang ilmu sains. Setiap individu mempunyai pandangan yang berbeda tentang pelajaran matematika. Ada yang memandang matematika sebagai mata pelajaran yang menyenangkan dan ada juga yang memandang matematika sebagai pelajaran yang sulit. Bagi yang menganggap matematika menyenangkan, maka akan tumbuh motivasi dalam diri individu tersebut untuk mempelajari matematika dan optimis dalam menyelesaikan masalah-masalah yang bersifat menantang dalam pelajaran matematika. Sebaliknya, bagi yang menganggap matematika sebagai pelajaran yang sulit, maka individu tersebut akan bersikap pesimis dalam menyelesaikan masalah matematika dan kurang termotivasi untuk mempelajarinya. Sikap-sikap tersebut tentunya akan mempengaruhi hasil yang akan mereka capai dalam belajar. Oleh karena itu, dalam membelajarkan matematika kepada siswa, apabila guru masih menggunakan paradigma pembelajaran lama dalam arti komunikasi dalam pembelajaran matematika cenderung berlangsung satu arah umumnya dari guru ke siswa, guru lebih mendominasi pembelajaran, maka pembelajaran cenderung monoton, sehingga mengakibatkan siswa merasa jenuh. Pola pembelajaran guru aktif dengan siswa pasif ini mempunyai efektivitas pembelajaran yang rendah. Banyak cara yang dapat dilaksanakan agar siswa menjadi aktif, salah satunya yaitu dengan merubah paradigma pembelajaran.

Berdasarkan kenyataan yang terjadi saat observasi di lapangan, diperoleh informasi bahwa matematika merupakan salah satu mata pelajaran yang dianggap sulit oleh siswa Sekolah Menengah Pertama (SMP) Negeri 5 Madiun. Kesulitan pada matematika salah satunya disebabkan karena pembelajaran matematika kurang bermakna, siswa masih belum aktif terlibat dalam kegiatan pembelajaran, sehingga pemahaman siswa tentang konsep matematika sangat lemah. Hal ini terjadi karena pembelajaran matematika saat ini pada umumnya siswa menerima begitu saja apa yang disampaikan guru. Anggapan ini mengakibatkan beberapa siswa menjadi malas dalam belajar matematika, sehingga beberapa siswa masih enggan untuk ikut berperan aktif pada saat pembelajaran berlangsung. Keaktifan siswa merupakan salah satu hal yang penting dalam pembelajaran. Selama ini model pembelajaran yang sebagian besar digunakan oleh guru SMP Negeri 5 Madiun dalam mengajar adalah model pembelajaran langsung.

Sebagai upaya meningkatkan prestasi belajar matematika siswa, perlu dikembangkan suatu pembelajaran yang tepat, sehingga dapat memberikan kesempatan bagi siswa untuk bertukar pendapat, bekerja sama dengan teman, berinteraksi dengan guru, menggunakan maupun mengingat kembali konsep yang dipelajari.

Mengingat pentingnya pelajaran matematika untuk pendidikan, guru hendaknya lebih memilih berbagai variasi pendekatan, strategi dan metode yang sesuai dengan situasi, sehingga tujuan pembelajaran yang direncanakan akan tercapai. Perlu diketahui bahwa baik atau tidaknya suatu pemilihan model pembelajaran akan tergantung tujuan pembelajarannya, kesesuaian dengan materi pembelajaran, tingkat perkembangan siswa dan kemampuan guru dalam mengelola pembelajaran serta mengoptimalkan sumber-sumber belajar yang ada. Guru harus mempersiapkan model pembelajaran yang tujuannya mempermudah dalam pembelajaran matematika. Dalam hal ini, pemilihan model pembelajaran ini disesuaikan dengan bahan pelajaran dan melibatkan keaktifan siswa dalam pembelajaran agar lebih optimal dalam belajar. Guru harus merancang dan mempersiapkan model pembelajaran yang sesuai dengan karakteristik siswa dan materi yang akan disampaikan. Hal ini 
ditunjukan supaya proses pembelajaran matematika lebih aktif, kreatif, efektif dan menyenangkan.

Terkait dengan hal di atas, untuk mengatasi permasalahan yang dihadapi siswa dalam mempermudah pembelajaran matematika, salah satunya dengan menerapkan model pembelajaran yang sesuai dengan karakteristik siswa. Dua diantaranya adalah termasuk model pembelajaran kooperatif (cooperative learning), yaitu model pembelajaran Artikulasi dan model pembelajaran Talking Stick. Kedua model pembelajaran tersebut menuntut keaktifan siswa dalam pembelajaran agar lebih bermakna dalam belajar.

Model pembelajaran kooperatif dikembangkan berdasarkan teori belajar konstruktivisme. "Berdasarkan teori, bahwa siswa lebih mudah menemukan dan memahami konsep-konsep yang sulit jika mereka saling mendiskusikan masalah tersebut dengan temannya" (Mohamad Nur dan Prima Retno Wikandari, 2008: 8). Pelaksanaan prosedur model pembelajaran kooperatif dengan benar akan memungkinkan guru mengelola kelas lebih efektif.

Model pembelajaran Artikulasi merupakan pembelajaran yang melatih daya ingat, pendengaran, ketelitian atau kecermatan dan melatih mengungkapkan kesalahan secara lisan. Dengan demikian, siswa bukan lagi sebagai obyek pembelajaran, namun bisa juga berperan sebagai tutor bagi teman sebaya, sehingga menjadikan siswa memiliki motivasi yang tinggi karena didorong dan didukung dari rekan sebaya. Guru tetap memiliki peran, yaitu sebagai fasilitator dan motivator. Siswa diajak untuk ikut serta dalam semua proses pembelajaran baik secara mental maupun fisik, sehingga belajar aktif dapat diterapkan. Proses pembelajaran seperti ini akan menimbulkan kesan yang menarik karena suasana yang menyenangkan dan siswa merasa ada dalam proses pembelajaran tersebut, sehingga prestasi belajar matematika mereka dapat meningkat.

Model pembelajaran lain yang juga dapat untuk meningkatkan pemahaman materi siswa yakni model pembelajaran Talking Stick. Model pembelajaran ini mempunyai kelebihan, yaitu dapat untuk menguji kesiapan siswa, melatih siswa berpikir cepat, membiasakan siswa untuk membaca dan memahami materi dalam waktu yang singkat serta melatih siswa agar belajar terlebih dahulu sebelum mendapatkan pengajaran. Tetapi model pembelajaran ini juga mempunyai kelemahan, yaitu jika guru kurang dapat menguasai kelas, kelas akan menjadi gaduh.

\section{B. METODE PENELITIAN}

Penelitian ini dilaksanakan pada seluruh siswa SMP Negeri 5 Madiun, dan subjek penelitiannya adalah siswa kelas VIII. Sampel dalam penelitian ini terdiri dari 2 kelas, yaitu kelas VIII B kelompok Artikulasi sebagai kelas eksperimen dan kelas VIIIC kelompok Talking Stick sebagai kelas kontrol. Desain faktorial yang digunakan dalam penelitian ini adalah $2 \times 3$. Teknik pengambilan sampel dilakukan dengan cara cluster random sampling, dimana dibagi menjadi beberapa kelompok atau cluster. Setiap anggota yang berada di dalam cluster diambil secara acak. Variabel bebas dalam penelitian ini adalah model pembelajaran dan motivasi belajar siswa, dan variabel terikatnya adalah prestasi belajar matematika.

Metode pengumpulan data penelitian meliputi metode dokumentasi yang berupa hasil nilai UH, metode tes yang berupa 15 butir soal pilihan ganda pada pokok bahasan bangun ruang sisi datar, dan metode angket yang berupa 40 butir angket untuk mengetahui tingkatan motivasi belajar siswa. Setelah data diperoleh dari pelaksanaan penelitian yang dilaksanakan selanjutnya adalah pengujian terhadap data tersebut. Adapun pengujian data meliputi uji keseimbangan yang digunakan untuk menguji kelas eksperimen dan kelas kontrol. Uji keseimbangan pada penelitian ini menggunakan uji-t dengan uji prasyarat uji normalitas menggunakan metode Lilliefors dan uji homogenitas dengan Bartlett. Selanjutnya, uji hipotesis data dalam penelitian ini menggunakan analisis variansi dua jalan sel tak sama. Tujuan dari analisis variansi dua jalan ini adalah untuk menguji signifikansi faktor baris, faktor kolom dan kombinasi faktor baris dan kolom terhadap prestasi belajar, serta uji komparasi ganda. Jika hasil dari analisis variansi dua jalan sel tidak sama tersebut menunjukkan $\mathrm{H}_{0}$ nya ditolak, maka dilakukan uji komparasi ganda pasca anava dengan menggunakan metode Scheffe'.

\section{HASIL DAN PEMBAHASAN}

Sebelum penelitian ini dilakukan, terlebih dahulu harus dilakukan uji keseimbangan rata-rata antar populasi. Hal ini dilakukan untuk mengetahui keadaan kemampuan awal antara kedua populasi, yaitu kelas eksperimen dan kelas kontrol dalam kedudukan yang seimbang atau tidak. Adapun data 
yang digunakan sebagai kemampuan awal ketiga populasi ini adalah prestasi belajar matematika dari nilai matematika siswa pada UH semester ganjil kedua kelas.

\section{Rerata Tes Prestasi Belajar Matematika Siswa} dalam Model Pembelajaran dan Kategori Motivasi Belajar Siswa

Berdasarkan hasil uji keseimbangan yang telah dilakukan, diperoleh nilai $\mathrm{t}_{\mathrm{obs}}=0,734<1,960$ $=t_{\alpha}$, maka $H_{0}$ diterima, sehingga dapat disimpulkan bahwa kedua populasi mempunyai kemampuan awal yang sama atau seimbang. Selanjutnya, data yang digunakan dalam pengujian hipotesis adalah data prestasi belajar matematika siswa pada pokok bahasan bangun ruang sisi datar. Berikut disajikan rerata tes prestasi belajar matematika siswa dalam model pembelajaran dan kategori motivasi belajar siswa pada Tabel 1 .

TABEL 1

RERATA TES PRESTASI BELAJAR MATEMATIKA SISWA DALAM MODEL PEMBELAJARAN DAN KATEGORI MOTIVASI BELAJAR SISWA

\begin{tabular}{lcccc}
\hline \multirow{2}{*}{$\begin{array}{c}\text { Model } \\
\text { Pembelajara }\end{array}$} & \multicolumn{2}{c}{ Rata-rata Tes Prestasi } & \multirow{2}{*}{$\begin{array}{c}\text { Rerata } \\
\text { Marginal }\end{array}$} \\
\cline { 2 - 4 } & Tinggi & Sedang & Rendah & 274,3 \\
\hline Artikulasi & 95,5 & 89,7 & 89,1 & 247,07 \\
\hline Talking Stick & 87,85 & 87,55 & 71,67 & 247 \\
\hline $\begin{array}{l}\text { Rerata } \\
\text { Marginal }\end{array}$ & 183,35 & 177,25 & 160,77 & \\
\hline
\end{tabular}

\section{Uji Prasyarat}

Sebelum melanjutkan dalam uji hipotesis, salah satu syarat untuk analisis variansi adalah dilakukan uji normalitas dan uji homogenitas. Berikut perhitungan uji normalitas dan uji homogenitas disajikan secara berturut pada Tabel 2 dan Tabel 3.

TABEL 2

RANGKUMAN HASIL UJI NORMALITAS

\begin{tabular}{|c|c|c|c|c|}
\hline Sampel & $\mathbf{L}_{\text {obs }}$ & $\mathbf{L}_{\alpha}$ & $\begin{array}{c}\text { Keputusan } \\
\text { Uji }\end{array}$ & $\begin{array}{c}\text { Kesimp } \\
\text { ulan }\end{array}$ \\
\hline Artikulasi & 0,1587 & 0,1682 & $\mathrm{H}_{0}$ diterima & Norma \\
\hline Talking Stick & 0,1627 & 0,1682 & $\mathrm{H}_{0}$ diterima & Norma \\
\hline $\begin{array}{l}\text { Motivasi } \\
\text { belajar siswa } \\
\text { tinggi }\end{array}$ & 0,1949 & 0,220 & $\mathrm{H}_{0}$ diterima & $\begin{array}{l}\text { Norma } \\
1\end{array}$ \\
\hline $\begin{array}{l}\text { Motivasi } \\
\text { belajar siswa } \\
\text { sedang }\end{array}$ & 0,1217 & 0,1706 & $\mathrm{H}_{0}$ diterima & $\begin{array}{l}\text { Norma } \\
l\end{array}$ \\
\hline $\begin{array}{l}\text { Motivasi } \\
\text { belajar siswa } \\
\text { rendah }\end{array}$ & 0,1828 & 0,234 & $\mathrm{H}_{0}$ diterima & $\begin{array}{l}\text { Norma } \\
\text { l }\end{array}$ \\
\hline
\end{tabular}

TABEL 3

RANGKUMAN HASIL UJI HOMOGENITAS VARIANSI

\begin{tabular}{lcccc}
\hline $\begin{array}{c}\text { Populasi } \\
\text { Siswa }\end{array}$ & $\boldsymbol{\chi}^{\mathbf{2}}$ obs & $\boldsymbol{\chi}^{\mathbf{2}}{ }_{\boldsymbol{\alpha}}$ & $\begin{array}{c}\text { Keputusan } \\
\text { Uji }\end{array}$ & Kesimpulan \\
\hline Model & & & & Variansi \\
Pembelaj & 1,175 & 3,481 & $\mathrm{H}_{0}$ diterima & kedua \\
aran & & & & populasi \\
Motivasi & & & & Variansi \\
Belajar & 4,361 & 5,991 & $\mathrm{H}_{0}$ diterima & kedua \\
Siswa & & & & populasi \\
\hline
\end{tabular}

Hasil uji prasyarat pada tabel tersebut diperoleh kesimpulan bahwa sampel berasal dari populasi yang berdistribusi normal dan mempunyai variansi yang homogen.

\section{Uji Hipotesis}

Setelah prasyarat analisis variansi terpenuhi, dilakukan uji hipotesis analisis variansi dua jalan sel tak sama yang hasilnya seperti pada Tabel 4 .

\section{TABEL 4}

RANGKUMAN ANALISIS VARIANSI DUA JALAN SEL TAK SAMA

\begin{tabular}{lcccccc}
\hline \multicolumn{1}{c}{ Sumber } & JK & $\begin{array}{c}\mathbf{d} \\
\mathbf{k}\end{array}$ & $\mathbf{R K}$ & $\begin{array}{c}\boldsymbol{F}_{\boldsymbol{o b}} \\
\boldsymbol{s}\end{array}$ & $\boldsymbol{F}_{\boldsymbol{\alpha}}$ & Ket \\
\hline $\begin{array}{l}\text { Pembelajara } \\
\text { n (A) }\end{array}$ & 798,26 & 1 & $\begin{array}{c}798, \\
3\end{array}$ & 7,5 & 4,1 & $\begin{array}{l}\mathrm{H}_{0 \mathrm{~A}} \\
\text { ditolak }\end{array}$ \\
\hline $\begin{array}{l}\text { Motivasi } \\
\text { belajar (B) }\end{array}$ & 881,4 & 2 & $\begin{array}{c}440, \\
7\end{array}$ & 4,2 & 3,2 & $\begin{array}{l}\text { HoB } \\
\text { ditolak }\end{array}$ \\
\hline $\begin{array}{l}\text { Interaksi } \\
\text { (AB) }\end{array}$ & 59,9 & 2 & 29,9 & 0,3 & 3,2 & $\begin{array}{l}\mathrm{H}_{0 \mathrm{AB}} \\
\text { diterim } \\
\text { a }\end{array}$ \\
\hline Galat (G) & 5093,7 & 48 & $\begin{array}{c}106, \\
1\end{array}$ & - & - & \\
\hline Total (T) & 6833,3 & 53 & - & - & - & \\
\hline
\end{tabular}

Kesimpulan analisis variansi dua jalan sel tak sama berdasarkan Tabel 4 adalah 1) pada efek utama (A), siswa dengan model pembelajaran Artikulasi dan model pembelajaran Talking Stick menghasilkan prestasi belajar matematika yang berbeda, 2) pada efek utama (B), ketiga kategori motivasi belajar siswa memberikan efek yang berbeda terhadap prestasi belajar matematika, dan 3) pada efek interaksi (AB), tidak ada interaksi antara model pembelajaran yang digunakan dan motivasi belajar siswa terhadap prestasi belajar matematika.

Dari kesimpulan tersebut, diketahui bahwa $\mathrm{H}_{0 \mathrm{~A}}$ dan $\mathrm{H}_{0 \mathrm{~B}}$ ditolak, hal ini berarti bahwa:

a) $\mathrm{H}_{\mathrm{OA}}$ ditolak. Hal ini berarti pada model pembelajaran Artikulasi dan model pembelajaran Talking Stick berbeda prestasi belajarnya. Dalam kasus ini, karena variabel model pembelajaran hanya mempunyai 2 nilai (yaitu Artikulasi dan Talking Stick), maka untuk antar baris tidak perlu dilakukan komparasi pasca anava. Jika dilakukan komparasi ganda antara rataan model 
pembelajaran Artikulasi dan rataan model pembelajaran Talking Stick, dapat dipastikan bahwa $\mathrm{H}_{0}$ nya juga akan ditolak. Komparasi itu menjadi tidak berguna, karena anava telah menunjukkan bahwa $\mathrm{H}_{0 \mathrm{~A}}$ ditolak. Dari rataan marginal pada tabel 1 menunjukkan bahwa rataan prestasi belajar pada model pembelajaran Artikulasi lebih tinggi dari rataan prestasi belajar pada model pembelajaran Talking Stick, maka dapat disimpulkan bahwa siswa yang diberikan pembelajaran dengan model Artikulasi lebih baik prestasi belajarnya dibandingkan dengan siswa yang diberikan pembelajaran dengan model Talking Stick.

b) $\mathrm{H}_{\text {ов }}$ ditolak. Hal ini menunjukkan bahwa tidak semua motivasi belajar memberikan efek yang sama terhadap prestasi belajar. Dengan kata lain, pasti terdapat paling sedikit dua rataan yang tidak sama. Variabel motivasi belajar mempunyai 3 nilai (tinggi, sedang dan rendah), maka komparasi ganda perlu dilakukan untuk melihat motivasi belajar yang bagaimana yang secara signifikan mempunyai rataan yang berbeda. Uji lanjut yang digunakan dalam penelitian ini adalah uji Scheffe'. Rangkuman hasil analisis uji Scheffe' pada tingkat signifikan $\alpha=0,05$ dapat dilihat pada tabel 5 berikut.

TABEL 5

KOMPARASI RERATA PRESTASI BELAJAR MATEMATIKA ANTAR MOTIVASI BELAJAR SISWA

\begin{tabular}{cccc}
\hline $\boldsymbol{H}_{\boldsymbol{O}}$ & $\boldsymbol{F}_{\boldsymbol{o b s}}$ & $\begin{array}{c}\boldsymbol{2 . F} \\
\boldsymbol{\alpha}\end{array}$ & Keputusan Uji \\
\hline$\mu .1=\mu .2$ & 6,71 & 6,40 & $\mathrm{H}_{0}$ ditolak \\
\hline$\mu .1=\mu .3$ & 7,84 & 6,40 & $\mathrm{H}_{0}$ ditolak \\
\hline$\mu .2=\mu .3$ & 10,58 & 6,40 & $\mathrm{H}_{0}$ ditolak \\
\hline
\end{tabular}

Berdasarkan Tabel 5, diperoleh kesimpulan komparasi rerata antar kolom sebagai berikut. 1) Pada $F_{1-2}\left(\mu_{.1}=\mu_{.2}\right)$ diketahui bahwa nilai $H_{0}$ ditolak, artinya terdapat perbedaan signifikan antara prestasi belajar matematika siswa yang mempunyai motivasi belajar tinggi dengan prestasi belajar matematika siswa yang mempunyai motivasi belajar sedang. Ini berarti jika dilihat dari rerata marginalnya, siswa dengan motivasi belajar tinggi $(183,35)$ mempunyai prestasi belajar matematika yang lebih baik dibandingkan dengan siswa yang mempunyai motivasi belajar sedang $(177,25)$. 2) Pada $F_{1-3}\left(\mu_{.1}=\mu_{.3}\right)$ diketahui bahwa nilai $H_{0}$ ditolak, artinya terdapat perbedaan signifikan antara prestasi belajar matematika siswa yang mempunyai motivasi belajar tinggi dengan prestasi belajar matematika siswa yang mempunyai motivasi belajar rendah. Ini berarti jika dilihat dari rerata marginalnya, siswa dengan motivasi belajar tinggi $(183,35)$ mempunyai prestasi belajar matematika yang lebih baik dibandingkan dengan siswa yang mempunyai motivasi belajar rendah $(160,77)$. 3) Pada $F_{2-3}\left(\mu_{.2}=\mu_{.3}\right)$ diketahui bahwa nilai $\mathrm{H}_{0}$ diterima, artinya terdapat perbedaan signifikan antara prestasi belajar matematika siswa yang mempunyai motivasi belajar sedang dengan prestasi belajar matematika siswa yang mempunyai motivasi belajar rendah. Ini berarti jika dilihat dari rerata marginalnya, siswa dengan motivasi belajar sedang $(177,25)$ mempunyai prestasi belajar matematika yang lebih baik dibandingkan dengan siswa yang mempunyai motivasi belajar rendah $(160,77)$.

Dari analisis variansi dua jalan, diketahui bahwa $\mathrm{H}_{0 \mathrm{AB}}$ diterima, sehingga tidak perlu dilakukan uji lanjut pasca analisis variansi dengan metode Scheffe' untuk uji komparasi rerata antar sel pada kolom yang sama dan uji komparasi rerata antar sel pada baris yang sama. Berdasarkan kesimpulan pada hipotesis antar baris dan antar kolom, maka dapat disimpulkan bahwa pada setiap tingkat motivasi belajar siswa, model pembelajaran Artikulasi selalu lebih efektif dibandingkan model pembelajaran Talking Stick.

\section{TEMUAN ATAU DISKUSI}

Fuadi Susilo dalam penelitiannya yang berjudul "Penerapan Model Pembelajaran Artikulasi sebagai Upaya Meningkatkan Prestasi dan Aktivitas Belajar Fisika Siswa di SMP N 3 Ngawi Tahun 2009/2010" [1] menyimpulkan bahwa penerapan model pembelajaran Artikulasi dapat meningkatkan prestasi belajar fisika siswa kelas VII SMP N 3 Ngawi. Adapun persamaan dengan penelitian yang diambil peneliti, yaitu sama-sama menggunakan model pembelajaran Artikulasi, sedangkan perbedaan dengan penelitian yang peneliti ambil adalah yang pertama, yaitu penelitian dari judul di atas berbentuk PTK, sedangkan penelitian yang peneliti ambil yaitu penelitian kuantitatif. Kedua, penelitian pada judul di atas adalah penelitian Fisika, sedangkan penelitian yang peneliti ambil adalah Matematika. Ketiga, penelitian dari judul di atas menggunakan model pembelajaran Artikulasi saja, sedangkan pada penelitian yang peneliti ambil menggunakan model 
pembelajaran Artikulasi dan model pembelajaran Talking Stick. Keempat, penelitian pada judul di atas dilakukan pada siswa kelas VII SMP N 3 Ngawi, sedangkan yang peneliti lakukan pada siswa kelas VIII SMP Negeri 5 Madiun.

Penelitian yang dilakukan oleh Anatya Christiana Saktiono yang berjudul "Efektifitas Model Pembelajaran Artikulasi dan Pembelajaran Cooperative Script Terhadap Prestasi Belajar Matematika Ditinjau dari Minat Belajar Siswa Kelas VII SMP Negeri 1 Bendo" [2] menyimpulkan bahwa prestasi belajar matematika siswa kelas VII SMP Negeri 1 Bendo yang diajar dengan model pembelajaran Artikulasi lebih baik dari siswa yang diajar dengan model pembelajaran Cooperative Script. Judul penelitian yang akan dilaksanakan dalam penelitian ini adalah "Efektivitas Model Pembelajaran Artikulasi dan Model Pembelajaran Talking Stick Terhadap Prestasi Belajar Matematika Ditinjau dari Motivasi Belajar Pada Siswa Kelas VIII SMP Negeri 5 Madiun." Kesamaan dalam penelitian ini terletak pada model pembelajaran Artikulasi yang digunakan. Perbedaannya terletak pada model yang peneliti gunakan selain model pembelajaran Artikulasi, juga model pembelajaran Talking Stick, sedangkan dalam penelitian Anatya Christiana Saktiono menggunakan model pembelajaran Artikulasi dan model pembelajaran Cooperative Script. Penelitian yang dilakukan Anatya Christiana Saktiono pada siswa kelas VII SMP Negeri I Bendo, sedangkan yang peneliti lakukan pada siswa kelas VIII SMP Negeri 5 Madiun.

\section{E. SIMPULAN DAN SARAN}

Berdasarkan analisis data menggunakan analisis variansi dua jalan dengan sel tak sama, diperoleh kesimpulan bahwa 1) model pembelajaran Artikulasi lebih efektif dibanding model pembelajaran Talking Stick; 2) Tingkat motivasi belajar mempengaruhi prestasi belajar matematika, terlihat bahwa siswa yang memiliki motivasi belajar tinggi, prestasi belajarnya jauh lebih baik dibandingkan dengan siswa yang memiliki motivasi belajar sedang maupun rendah, dan siswa yang memiliki motivasi belajar rendah, prestasi belajarnya jauh lebih baik dibandingkan dengan siswa yang memiliki motivasi belajar rendah; 3) model pembelajaran Artikulasi lebih efektif dari model pembelajaran Talking Stick untuk meningkatkan prestasi belajar siswa, baik pada setiap tingkat motivasi belajar siswa.
Sesuai dengan simpulan dari penelitian ini, maka peneliti memberikan saran sebagai berikut. 1) Bagi guru, dalam usaha meningkatkan prestasi belajar siswa, diharapkan guru benar-benar bisa memposisikan diri sebagai fasilitator dan motivator dalam kegiatan belajar siswa. Guru sebaiknya lebih meningkatkan kinerja dan kreativitas dalam memecahkan permasalahan yang terjadi di kelas, melatih kemampuan siswa untuk mengungkapkan pendapat dan mengemukakan ide yang dimiliki dan memperhatikan pula motivasi belajar yang dimiliki siswa. Selain itu, hendaknya guru menggunakan model-model pembelajaran yang berbeda sesuai dengan materi yang diajarkan, salah satunya yaitu dengan menggunakan model pembelajaran Artikulasi. 2) Bagi peneliti lain, Dengan segala keterbatasan dalam penelitian ini, maka perlu dilaksanakan penelitian serupa dengan melibatkan tenaga-tenaga pendidikan yang lebih berkompeten, waktu penelitian yang lebih leluasa dan diterapkan pada subjek serta materi yang berbeda.

\section{UCAPAN TERIMA KASIH}

Ucapan terimakasih sebesar-besarnya kepada Bapak Almiqdad S.Pd., M.Pd., selaku Kepala Sekolah SMP Negeri 5 Madiun yang telah memberi ijin penelitian; Ibu Endah Kusmintarsih S.Pd. dan Ibu Supriyati S.Pd., selaku guru mata pelajaran matematika kelas VIIIB dan VIIIC SMP Negeri 5 Madiun; semua siswa dan siswi kelas VIII, Bapak dan Ibu Guru beserta staf SMP Negeri 5 Madiun; serta keluarga yang selalu memberi do'a, semangat dan dukungan moril maupun materiil.

\section{REFERENSI}

[1] Nur, M. dan Wikandari, P. R. (2008). Pengajaran Berpusat Kepada Siswa dan Pendekatan Konstruktivis dalam Pengajaran, Universitas Negeri Surabaya, Surabaya

[2] Saktiono, A. C. (2011). Efektifitas Model Pembelajaran Artikulasi dan Pembelajaran Cooperative Script Terhadap Prestasi Belajar Matematika Ditinjau Dari Minat Belajar Siswa Kelas VII SMP Negeri 1 Bendo, IKIP PGRI Madiun, Madiun

[3] Subana dan Sudrajat. (2001). Dasar-Dasar Penelitian Ilmiah. Bandung: Pustaka Setia.

[4] Sudjana. (2005). Metode Statistika. Bandung: Tarsito.

[5] Susilo, F. (2010). Penerapan Model Pembelajaran Artikulasi Sebagai Upaya Meningkatkan Prestasi dan Aktivitas Belajar Fisika Siswa di SMP N 3 Ngawi Tahun 2009/2010, IKIP PGRI Madiun, Madiun

[6] Sugiyono. (2010). Metode Penelitian Pendidikan. Bandung: Alfabeta 